\section{Environmental niche and distribution of six deciduous tree species in the Spanish Atlantic region}

\author{
Jose V Roces-Díaz ${ }^{(1)}$, Borja Jiménez-Alfaro ${ }^{(2)}$, Pedro Álvarez-Álvarez ${ }^{(1)}$, \\ Miguel A Álvarez-García ${ }^{(3)}$
}

Understanding the influence of environmental factors on the distribution of tree species is essential for developing management actions at regional level. We developed species distribution models for six European tree species to determine their potential niche in the Spanish Atlantic region, where deciduous forests are relatively well preserved. Data from the national Forest Inventory and topo-climatic and soil variables were used to construct distribution models by using Generalized Linear Models. The main factor accounting for the current geografic distribution of the selected species were minimum winter temperature and mineral fertility of soils. Suitable habitats for Quercus petraea and $F$. sylvatica were mainly high-altitude areas with low minimum temperatures. In contrast, $Q$. robur and $C$. sativa were restricted to low altitudes and warmer conditions. Betula pubescens was not influenced by the elevation, probably because its adaptation to Atlantic conditions, though its distribution was associated with low fertility soils. Although the submediterranean $Q$. pyrenaica was positively influenced by the slope, model performance was poor for this species, possibly because of the truncated environmental range of the species in the study area. The findings suggest that temperature rather than moisture is shaping the distribution of deciduous trees at the southern limit of the Atlantic biogeographic region. Strong elevational difference between the warm coast and the cold mountains may determine the geographical disjunction between $Q$. robur and $Q$. petraea in southern Europe.

Keywords: Species Distribution Models, Topo-climatic Variables, Quercus species, Fagus sylvatica, Castanea sativa, Betula pubescens, Iberian Peninsula, Deciduous Forests

\section{Introduction}

The temperate mid-latitude ecozone of the northern hemisphere is mainly distributed in the Atlantic regions of North America and Europe and also in central Europe (Schultz 2005). The climax vegetation of this ecozone consists of temperate deciduous forests, which dominate from sea level to the subalpine zone. These ecosystems comprise some of the main components of European landscapes (Meeus 1995) and provide the society with important flow of services (MA 2005, Harrison et al. 2010). The main ecosystem services provided by forests are regulation processes, such as soil protection, climate, etc., although provision of cultural services is also important.

The distribution of tree species in Europe is mainly determined by climatic factors (Svenning \& Skov 2004, 2007), despite the effect of historical factors such as the presence of glacial refuges (Muñoz Sobrino et al. 2006, Willner et al. 2009) and naturalization of species beyond their former range. The dominant forest tree species in the temperate mid-latitude ecozone are taxonomical- ly related, most belonging to the Fagaceae family. These species require a minimum of 120 days per year with an average temperature above $10^{\circ} \mathrm{C}$, and most of them grow in areas where winter is shorter than 4 months (Walter 1979) and frost damage is a secondary factor. Although it has been suggested that minimum temperature is one of the main determinants for the growth and development of native trees (Sykes et al. 1996), other climatic variables and soil factors are also expected to shape the distribution of tree species (Ashcroft et al. 2011).

Several attempts have been made to characterize the ecological niche and spatial distribution of forest tree species in Europe (Sykes et al. 1996, Brus et al. 2011, Casalegno et al. 2011). However, biogeographical regions differ in terms of historical and climatic factors. A better understanding of species-environment relationships requires data sources spanning over large areas with high spatial resolution (e.g., National Forest Inventories - NFI), to be used for the development of climatic models, with the aim of analyzing particular areas and assessing the
(1) GIS-Forest Group, Department of Organisms and Systems Biology, University of Oviedo, E-33993 Mieres (Spain); (2) Department of Botany and Zoology, Masaryk University, CZ-61137 Brno (Czech Republic); (3) INDUROT, Department of Organisms and Systems Biology, University of Oviedo, E33993 Mieres (Spain)

@ Jose V Roces-Díaz (jvroces@gmail.com)

Received: Nov 18, 2013 - Accepted: May 31, 2014

Citation: Roces-Díaz JV, Jiménez-Alfaro B, Álvarez-Álvarez P, Álvarez-García MA, 2015. Environmental niche and distribution of six deciduous tree species in the Spanish Atlantic region. iForest 8: 214-221 [online 2014-08-28] URL: http://www.sisef.it/ iforest/contents/?id=ifor1183-008

Communicated by: Emanuele Lingua

influence of environmental conditions. Computing species distribution models (SDMs Guisan \& Thuiller 2005, Elith \& Leathwick 2009) applied on such data may be especially useful for defining the environmental niche of tree species and for assessing their potential distribution at regional scales.

In this study, we applied SDMs on species occurrence data from the Spanish NFI to compare the climatic niche of six European tree species in the Atlantic region, at the southern distribution limit of temperate deciduous forests in Europe. The studied region is characterized by an oceanic and relatively warm climate and representing a unique environmental zone in Europe (the $\mathrm{Lu}$ sitanian zone, according to Metzger et al. 2005). The study area was the Autonomous Community of Asturias, one of the most densely forested areas of the Iberian peninsula, where deciduous forests are relatively well preserved. Asturias is characterized by an elevational gradient ranging from the sea level to altitudes often higher than $2000 \mathrm{~m}$ a.s.l., by far the strongest altitudinal gradient found across the entire European Atlantic region. According to local vegetation surveys, the distribution of tree species is determined by strong climatic gradients and soil conditions (Díaz \& Fernández-Prieto 1994), although it is unknown whether local environmental gradients affect the ecological niche of forest trees. Thus, Asturias provides a good study system for investigating the environmental niche of European tree species in oceanic temperate climates with high topographic heterogeneity.

Understanding the ecological determinants that affect the distribution of forest tree species in this region is important for planning appropriate management actions aimed at preventing the potential impacts of climate 


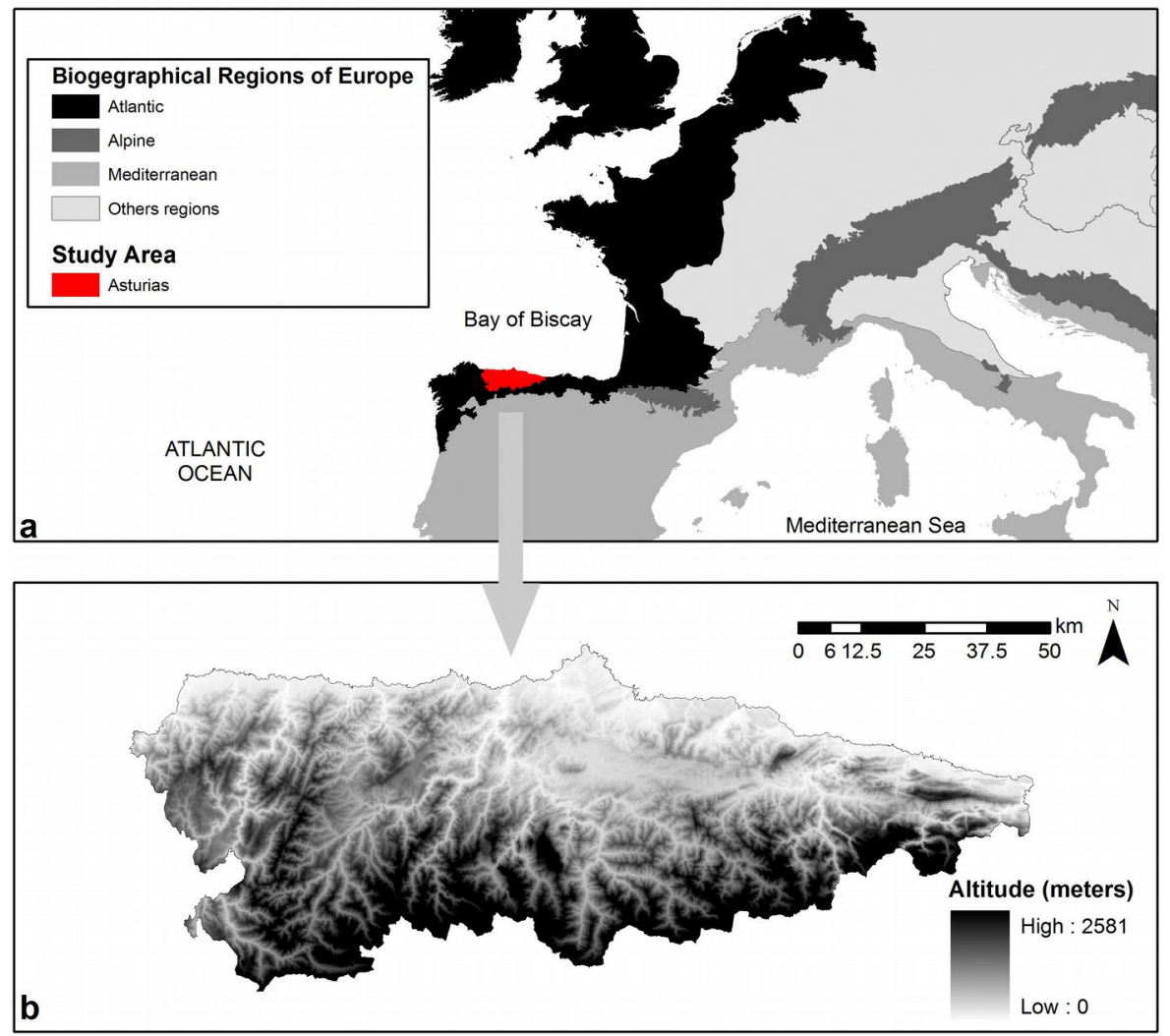

Fig. 1 - Map of the study area. (a): location of Asturias in the European Biogeographical Atlantic Region (source: EEA 2011). (b): Digital elevation model of Asturias (source: IGN 2013). change in southern Europe (Benito Garzón et al. 2008). It is worth noting that native forests from this area are rarely monospecific, including one or more dominant species, and mixtures of different tree structures as well. Niche overlapping is therefore possible for these species, and the analysis of such overlap could help improve our understanding of forest distribution.

The main aims of this study were: (i) to investigate how environmental factors determine the distribution of main tree species in deciduous forests; and (ii) to delineate the potential distribution ranges of these species at high-resolution scale. In addition, we discuss whether the factors driving the forest tree species' occurrence in the Spanish At-

lantic Region are similar to those previously reported for other European regions.

\section{Material and Methods}

\section{Study area and species}

The Autonomous Community of Asturias is part of the European Atlantic Region (EEA 2011) at the border with the Mediterranean Region (Fig. 1), and covers about $10600 \mathrm{~km}^{2}$ of which approximately $40 \%$ are forests. The area is one of the most densely forested regions in Spain (MMA 2003).

The climate is oceanic, with mean precipitation exceeding $800 \mathrm{~mm}$ year ${ }^{-1}$ and reaching more than $2000 \mathrm{~mm}$ year $^{-1}$ at highest elevations. Precipitation decreases in summer in

Tab. 1 - Mean values (and standard deviation) of the parameters used to describe the structure of forest stands analyzed in this study. Data from plots with more than 50 stems ha $^{-1}$ and coverage by the dominant species $>60 \%$ (source: MMA 2003).

\begin{tabular}{|c|c|c|c|c|c|c|c|c|}
\hline \multirow{2}{*}{$\begin{array}{l}\text { Dominant } \\
\text { species }\end{array}$} & \multicolumn{2}{|c|}{$\begin{array}{l}\text { Tree density } \\
\left(\text { stems ha }^{-1}\right)\end{array}$} & \multicolumn{2}{|c|}{$\begin{array}{c}\text { Basal area } \\
\left(\mathbf{m}^{2} \mathbf{h a}^{-1}\right)\end{array}$} & \multicolumn{2}{|c|}{$\begin{array}{c}\text { Quadratic mean } \\
\text { diameter }(\mathrm{cm})\end{array}$} & \multicolumn{2}{|c|}{$\begin{array}{l}\text { Dominant } \\
\text { height }(m)\end{array}$} \\
\hline & mean & SD & mean & SD & mean & SD & mean & SD \\
\hline Q. robur & 449.52 & 396.8 & 15.33 & 10.05 & 23.39 & 10.41 & 12.17 & 4.18 \\
\hline Q. petraea & 342.04 & 243.5 & 18.92 & 12.7 & 28.27 & 13.88 & 12.89 & 4.46 \\
\hline Q. pyrenaica & 543.26 & 600.15 & 14.25 & 12.54 & 19.3 & 8.39 & 10.96 & 4.73 \\
\hline F. sylvatica & 526.43 & 420 & 26.13 & 10.64 & 29.77 & 12.48 & 17.18 & 4.21 \\
\hline C. sativa & 785.1 & 668.61 & 24.73 & 17.91 & 23.61 & 14.07 & 13.99 & 3.64 \\
\hline B. pubescens & 645.7 & 560.32 & 15.02 & 10.1 & 17.80 & 6.86 & 12.19 & 4.72 \\
\hline
\end{tabular}

some areas, but physiological drought does not occur in any part of the study area. Forest wildfires in this region are less intense and affect smaller areas than in the Mediterranenan region (Álvarez \& Marquínez 2007).

Human impacts on woodlands in Asturias began two thousand years ago (Muñoz-Sobrino et al. 2005), but during the last century human activity has deeply transformed most accessible areas at low and medium altitudes $(<1000 \mathrm{~m}$ a.s.l.). Nowadays, timber production using fast growing species such as Eucalyptus spp. and Pinus spp. are widespread at low altitudes, while remnants of natural forests are scattered amongst meadows and heathlands used for livestock. In montane areas, forests are more abundant though fragmented (Garcia et al. 2005). Timber line is represented by deciduous forests and rarely exceeds $1700 \mathrm{~m}$ a.s.l. (Díaz \& FernándezPrieto 1987).

In this study, six main native tree species occurring in the study area were chosen (Tab. 1): Quercus robur L., Q. petraea (Matt.) Liebl., Q. pyrenaica Willd., Fagus sylvatica L., Castanea sativa Mill., and Betula pubescens Ehrh (sometimes referred to as $B$. pubescens subsp. celtiberica or $B$. celtiberica). These species may be found as dominant trees (except $C$. sativa) in mixed forests, along with other minor species such as Fraxinus excelsior L., Salix spp., Ilex aquifolium L. and Acer pseudoplatanus L.

\section{Data collection}

Information on species cover was drawn from the Spanish National Forest Inventory (NFI - MMA 2003), based on a regular grid of $1 \times 1 \mathrm{~km}$ covering the whole forested territory. For each grid node, data on the presence and cover of tree species in circular plots (radius $25 \mathrm{~m}$ ) were available. Presence/absence of the six target species for 1877 plots falling within the study area were then imported in a GIS database (ArcGIS 9.3, ESRI, Redlands, CA, USA). The minimum distance of $1 \mathrm{~km}$ between plots was chosen to prevent the inclusion of spatially autocorrelated data. Climatic and topographic data were compiled from the Climatic Digital Atlas of the Iberian Peninsula (Ninyerola et al. 2005), available in grid format with a cell size of $200 \mathrm{~m}$. Climatic data consisted of the following variables (Tab. 2): (i) annual precipitation (PREC); (ii) annual mean temperature (T); (iii) mean temperature of the coldest month (TMIN); (iv) index of continentality (IC), i.e., the difference between the mean temperatures of hottest and coldest months (Tuhkanen 1980); and (v) potential evapotranspiration for July (ETP), representing the maximal evaporation in a given area without water limitation in the driest month (Thornthwaite 1948). Three topography-related variables were also considered: (vi) altitude 
Tab. 2 - Description of the variables considered as possible predictors of the geographic distribution of the six target species. (a): Semiquan titative classification from 1 (lowest) to 4 (highest).

\begin{tabular}{|c|c|c|c|c|}
\hline Variable & Description & Unit & Source & $\begin{array}{l}\text { Cell size } \\
\text { (m) }\end{array}$ \\
\hline ALT & Altitude based on a Digital Elevation Model & $\mathrm{m}$ & IGN 2013 & 10 \\
\hline SLOPE & Slope based on a Digital Elevation Model & $\%$ & IGN 2013 & 10 \\
\hline RAD & Accumulated radiation during one year & $\mathrm{kJ} \mathrm{m}^{-2}$ year $^{-1}$ & Ninyerola et al. 2005 & 200 \\
\hline PREC & Accumulated precipitation during one year & $\mathrm{mm}$ & Ninyerola et al. 2005 & 200 \\
\hline TEMP & Mean annual temperature & ${ }^{\circ} \mathrm{C}$ & Ninyerola et al. 2005 & 200 \\
\hline TMIN & Mean temperature of daily minimum during January & ${ }^{\circ} \mathrm{C}$ & Ninyerola et al. 2005 & 200 \\
\hline IC & $\begin{array}{l}\text { Difference between monthly temperatures of hottest month and } \\
\text { coldest month }\end{array}$ & ${ }^{\circ} \mathrm{C}$ & Ninyerola et al. 2005 & 200 \\
\hline PET & $\begin{array}{l}\text { Maximum evaporation occurring on ground totally covered by } \\
\text { vegetation and without water limitations during the driest month }\end{array}$ & $\mathrm{mm}$ & Ninyerola et al. 2005 & 200 \\
\hline FERTI & Soil fertility based on lithological factors & 1 to $4^{\text {(a) }}$ & Fernández-Menéndez 2002 & 200 \\
\hline
\end{tabular}

(ALT); (vii) slope (SLOPE); and (viii) solar radiation (RAD); and one variable related to soil $\mathrm{pH}$ : (viii) fertility (FERTI), determined for the study area by combining geological and lithological digital maps to reflect the amount of carbonates and soil depth (Fernández-Menéndez 2002).

Pairwise Pearson's correlation coefficients $(r)$ were calculated between variables to assess their collinearity, excluding those with $r>0.6$. FERTI, SLOPE, RAD and PREC were not significantly related to any other variable. ALT and TEMP were closely correlated with several of the other factors and therefore discarded from further analysis TMIN, IC and ETP were correlated with each other. As TMIN is a meaningful factor related to the winter temperatures and frost probability, it was preserved as a more informative predictor, and the other two factors then discarded.

\section{Distribution models}

In order to model the spatial distribution of each of the six target species analyzed, Generalized Linear Models (GLMs) were constructed using a binomial distribution with a logistic link function in SPSS 17.0 for Windows (SPSS Inc. 2008). The dependent variable was binary and reflects the presence (1) or absence $(0)$ of each species in each plot. The dataset of each species was implemented in ArcGIS 9.3 to built an equal proportion of presences and absences (50\%). Using a random selection procedure, we selected $80 \%$ of the grid points for model calibration and the remaining $20 \%$ for the next validation step. The sample size was 1816 for Q. robur, 508 for Q. petraea, 630 for $Q$. pyrenaica, 832 for $F$. sylvatica, 1690 for $C$. sativa, and 1588 for $B$. pubescens.

Independent variables in GLMs were selected using the Wald's backward stepwise procedure. The performance of each model was assessed by a confusion or error matrix that crosstabulates the observed and predicted presence/absence patterns (Fielding \& Bell 1997). Model validation was performed using the Area Under the ROC Curve (AUC - Fielding \& Bell 1997). AUC values can range from 0.5 (performance equal to random) to 1.0 (perfect fit). For assessing distribution models, AUC values in the range 0.50.7 were considered low, 0.7-0.9 were moderate and $>0.9$ were high, suggesting poor, good and very good model performances, respectively (Swets 1988). For each of the six models considered, Moran's $I$ statistic was also computed to evaluate the spatial autocorrelation of residuals after accounting for the effect of the environmental variables, using the Spatial Analyst tool in ArcGIS (Elith \& Leathwick 2009).

The coefficients from the GLMs obtained were used to predict the probability of occurrence of the target species in the whole study area at a grid size of $200 \times 200 \mathrm{~m}$. Predicted

values ranging from 0 to 1 were interpreted in terms of habitat suitability, i.e., the probability of finding suitable environmental conditions for each species according to the set of variables included in the models. Finally, Pearson's correlation coefficients between predicted and observed data were calculated for each species using a random selection of 1000 grid points over the study area.

\section{Results}

The results from the GLM analysis revealed differences among those environmental variables that determine the occurrence of the analyzed species (Tab. 3). The model for Q. robur, which included all the variables considered, revealed that the presence of this species was positively related to TMIN, RAD and PREC, and negatively related to

Tab. 3 - Results of the GLM modeling for each of the six target species. (B): coefficients of the model; (Wald): statistics used in the variable selection process; (AUC): accuracy parameter used for validation.

\begin{tabular}{llccccc}
\hline Model & Variable & B & Range & Mean & Wald & AUC \\
\hline Quercus & TMIN & 0.039 & $4-13.2$ & 9.6 & 98.232 & 0.76 \\
robur & FERTI & -0.182 & $1-4$ & 2.64 & 13.568 & \\
& SLOPE & -0.021 & $0.5-40.6$ & 15.2 & 6.505 & \\
& RADI & 0.001 & $1134-2369$ & 1920 & 16.403 & \\
& PREC & 0 & $714-2034$ & 1273 & 2.91 & \\
& constant & -6.101 & - & - & 38.029 & \\
\hline Quercus & TMIN & -0.035 & $4.6-13.2$ & 9.2 & 34.088 & 0.753 \\
petraea & constant & 3.243 & - & - & 33.314 & \\
Quercus & SLOPE & 0.042 & $0.4-37.9$ & 15.8 & 11.755 & 0.569 \\
pyrenaica & PREC & 0 & $755-1767$ & 1258 & 5.524 & \\
& constant & 0.746 & - & - & 1.647 & \\
\hline Fagus & TMIN & -0.084 & $4.0-13.1$ & 9.1 & 133.138 & 0.861 \\
sylvatica & FERTI & 0.707 & $1-4$ & 2.93 & 52.607 & \\
& RADI & -0.003 & $1145-2369$ & 1874 & 37.96 & \\
& constant & 11.783 & - & - & 98.443 & \\
\hline Castanea & TMIN & 0.07 & $4.0-13.2$ & 9.6 & 262.284 & 0.758 \\
sativa & PREC & 0 & $636-2034$ & 1276 & 7.49 & \\
& constant & -5.474 & - & - & 69.797 & \\
\hline Betula & FERTI & -0.424 & $1-4$ & 2.61 & 68.993 & 0.627 \\
pubescens & SLOPE & -0.037 & $0.1-39.8$ & 15 & 20.94 & \\
& RADI & 0 & $1134-2360$ & 1919 & 5.689 & \\
& PREC & 0 & $636-2034$ & 1272 & 8.7 & \\
& constant & 4.345 & - & - & 77.087 & \\
\hline
\end{tabular}



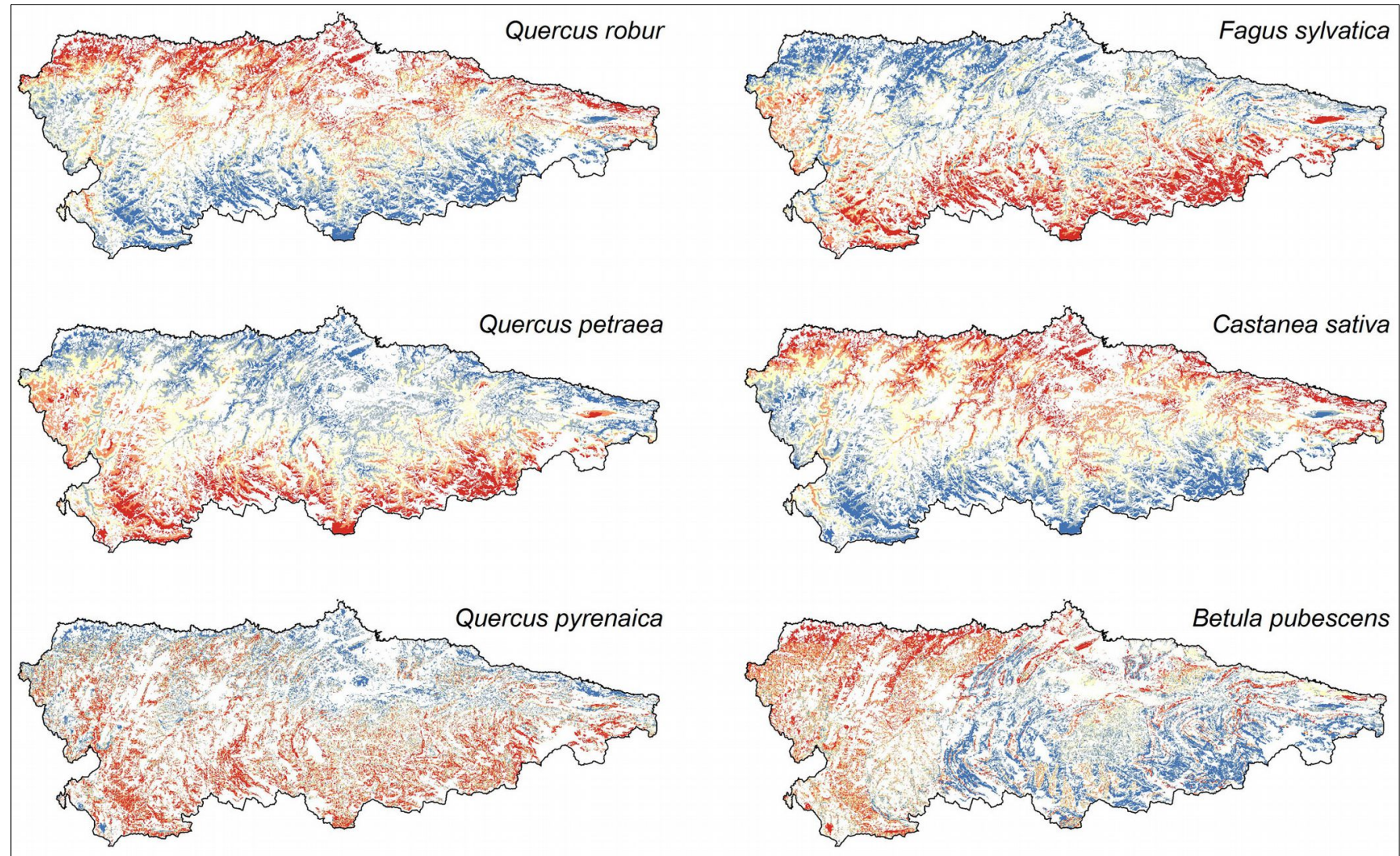

\section{HABITAT SUITABILITY}

VERY LOW

LOW

MEDIUM

$\mathrm{HIGH}$

VERY HIGH

Fig. 2 - Results of the modeling of habitat suitability for the six species analyzed. Non-forest areas were excluded from the analysis (dis played in white in the maps).

FERTI and SLOPE. The AUC value for this model (0.760) indicates a good performance. The $Q$. petraea model provided a similar accuracy $(\mathrm{AUC}=0.753)$, although in this case the only variable included was TMIN and its effect was negative. Although the $Q$. pyrenaica model was the least accurate (AUC $=$

Tab. 4 - Probability thresholds for the five habitat suitability classes.

\begin{tabular}{lccccc}
\hline \multirow{2}{*}{ Model } & \multicolumn{5}{c}{ Suitability classes } \\
\cline { 2 - 6 } & Very Low & Low & Medium & High & Very High \\
\hline Q. robur & $<0.10$ & $0.10-0.19$ & $0.19-0.29$ & $0.29-0.41$ & $0.41-0.79$ \\
Q. petraea & $<0.31$ & $0.31-0.39$ & $0.39-0.51$ & $0.51-0.65$ & $0.65-0.96$ \\
Q. pyrenaica & $<0.75$ & $0.75-0.79$ & $0.79-0.83$ & $0.83-0.87$ & $0.87-0.98$ \\
F. sylvatica & $<0.13$ & $0.13-0.26$ & $0.26-0.51$ & $0.51-0.83$ & $0.83-0.99$ \\
C. sativa & $<0.46$ & $0.46-0.74$ & $0.74-0.88$ & $0.88-0.93$ & $0.93-0.99$ \\
B. pubescens & $<0.88$ & $0.88-0.92$ & $0.92-0.94$ & $0.94-0.96$ & $0.96-0.99$ \\
\hline
\end{tabular}

Tab. 5 - Results of the Pearson's correlation analysis between habitat suitability for the different species analyzed. $(* *): \mathrm{p}<0.01$.

\begin{tabular}{lccccc}
\hline Pearson $\boldsymbol{r}$ & Q. petraea & Q. pyrenaica & F. sylvatica & C. sativa & B. pubescens \\
\hline Q. robur & $-0.839^{* *}$ & $-0.44^{* *}$ & $-0.876^{* *}$ & $0.81^{* *}$ & $0.35^{* *}$ \\
Q. petraea & - & $0.404^{* *}$ & $0.87^{* *}$ & $-0.938^{* *}$ & $0.057^{* *}$ \\
Q. pyrenaica & - & - & $0.38^{* *}$ & $-0.283^{* *}$ & $0.14 * *$ \\
F. sylvatica & - & - & - & $-0.834^{* *}$ & $-0.11^{* *}$ \\
C. sativa & - & - & - & - & $0.102^{* *}$ \\
\hline
\end{tabular}

formance was similar to that obtained for $Q$. robur and $Q$. petraea $(0.758)$, revealing that the species presence was positively related to TMIN. Finally, for B. pubescens model performed rather poorly $(\mathrm{AUC}=0.627)$, showing that the presence of this species was negatively correlated with FERTI and SLOPE.

The predicted spatial pattern of habitat suitability clearly differed among species, although some similarities were observed (Fig. 2 and Tab. 4). Habitat suitability of C. sativa and $B$. pubescens was "high" to "very high" over more than $50 \%$ of the area, with a wide range of variation, while for the other species the range was narrower (10 to $28 \%$ ). Calculations of Moran's $I$ detected positive values of spatial autocorrelation of residuals for Quercus petraea $(I=0.543, P=0.00)$ and Betula pubescens $(I=0.51, P=0.03)$ models, and a stronger clustering for Castanea sativa $(I=0.81, P=0.00)$. The remaining species were randomly distributed.

Highest suitability values for $Q$. robur and C. sativa were observed in the northern half of the study area, mainly at low altitudes (Fig. 3). Analogously, the least suitable areas for both species were the elevated mountain 
Fig. 3 - Area $\left(\mathrm{km}^{2}\right)$ of the five habitat suitability classes for each species based on three different altitudinal ranges: $<500 \mathrm{~m} ;$ 500-1000 m; $>1000 \mathrm{~m}$.
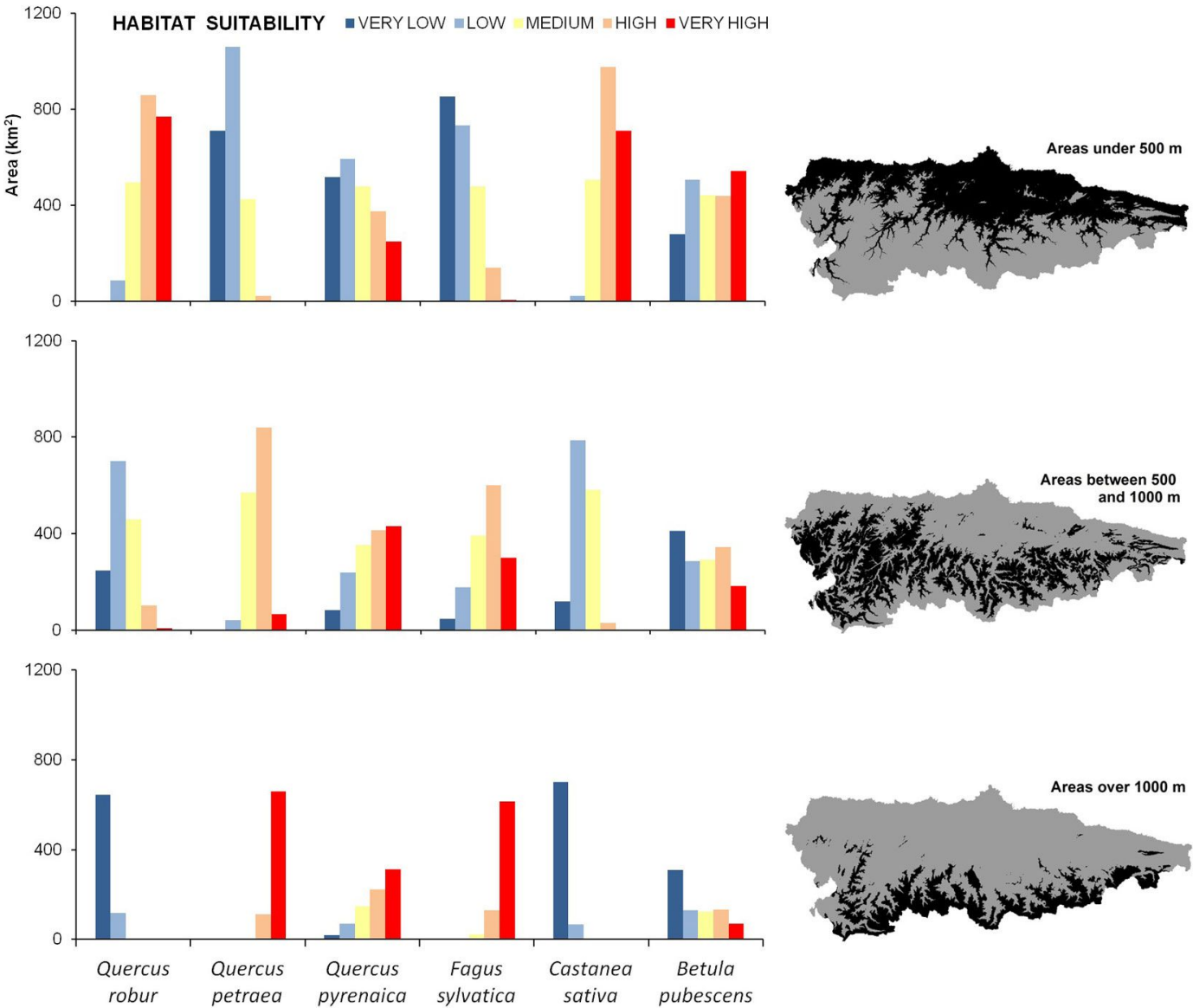
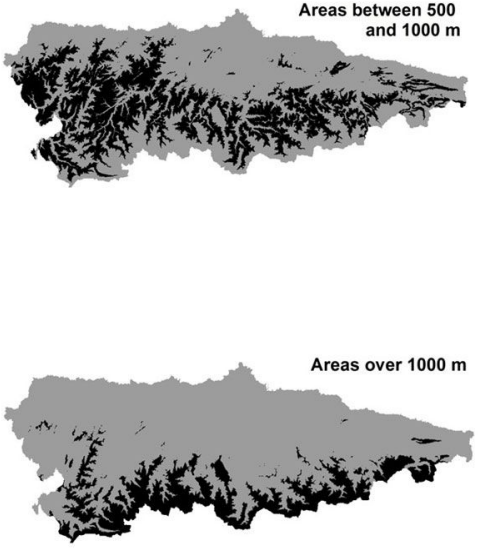

slopes at the southern limit of the study area (Fig. 3). By contrast, the highest suitability values for $F$. sylvatica and $Q$. petraea ranged from intermediate altitudes to approximately $1300 \mathrm{~m}$ a.s.l. The suitability values for $Q$. pyrenaica were quite similar to those obtained for F. sylvatica and Q. petraea, as they showed a certain preference for intermediate altitudes (Fig. 3). However, suitable areas for $Q$. pyrenaica were less continuous than for other species.

The correlations between habitat suitability for the different species analyzed clearly revealed two main groups of species: those associated with low altitudes $(Q$. robur and $C$. sativa) and those preferring mountainous areas ( $F$. sylvativa and $Q$. petraea - Tab. 5). Correlation coefficients between suitability of $Q$. pyrenaica and B. pubescens and suitability for any of the other species were always $<0.5$, suggesting the presence of different ecological niches across the study area.

\section{Discussion}

The findings of this study reveal the main environmental factors driving the distribution of six European tree species in Asturias, a region characterized by a temperate oceanic climate and a unique elevational gradient in the context of the Atlantic biogeographic region in Europe. The study area represents the southern margin of the distribution for Fagus sylvatica, Quercus petraea, Quercus robur and Betula pubescens, which are common in the Atlantic region but not in the Mediterranean region.

We found that the minimum temperature (TMIN) had a strong influence on species distribution. Such factor has been considered critical in shaping the geographical distributions of plants (Ashcroft et al. 2011). Indeed, minimum temperature can be used as a surrogate for winter conditions, reflecting the ability of some species to resist frost damage. Given the Atlantic influence in the study area, it is not surprising that precipitation (PREC) had scant influence on the distribution of the analyzed species, unlike other studies carried out in the Mediterranean region, where this is critical factor affecting the transitions between forest types (e.g., Quercus ilex and Quercus faginea forests Ninyerola et al. 2010). Soil fertility (FERTI) was also found to be an important predictor of the spatial distribution of species, according to previous studies that used soil properties as predictors in species distribution models (Gaston et al. 2009).

Model performances were generally satisfactory, except for Quercus pyreanica and, to a lesser extent, Betula pubescens. As we discuss below, the poor model performance of $Q$. pyrenaica can be explained by the scarce representation of the species in the study area, which generates a truncated niche. In contrast, the poor model performance for $B$. pubescens may be explained by the common occurrence of such species in the whole study area, regardless the changes in the factors analyzed along the enviromental gradients considered. We also detected spatial autocorrelation of model residuals for few species, in particular for Castanea sativa. However, spatial effects in species distribution models has been shown not to influence results in large datasets (Record et al. 2013). In our study, spatial autocorrelation in the $C$. sativa dataset suggests that the distribution of this species is closely related to factors not included in the current analysis. Considering that our sampling was based on well-separated spatial units $(1 \mathrm{~km})$, this effect is possibly related to human activities favoring the development of chestnut in particular areas.

Fagus sylvatica and Quercus petraea showed a strong preference for montane areas. These species are widely distributed and predominant in cool regions of central Europe (Sykes et al. 1996), where they often share environmental niches. Recent distribution models based on different climatic scenarios have predicted in the next few decades an enlargement of their range in northern Europe (European Commission 2012), as a 
consequence of the expected increase in minimum winter temperatures. Our results confirm that winter temperature affects the distribution of both species in the Spanish Atlantic region, and therefore similar shifts to higher altitudes (rather than higher latitudes) are expected in the future.

The geographic distribution of $F$. sylvatica has traditionally been related to a relatively long vegetative period, high moisture and high degree of continentality (Fang \& Lechowicz 2006), variables that are negatively related to TMIN. Sánchez et al. (2003) reported an optimal distribution for this species (in an area close to the present study area) on northern slopes above $600 \mathrm{~m}$ a.s.l with mean annual temperature ranging between 6.1 and $10.5^{\circ} \mathrm{C}$. The optimal conditions described for beech by these authors imply annual rainfall higher than $950 \mathrm{~mm}$ with no drought and an upper altitudinal limit of approximately $1500 \mathrm{~m}$ a.s.1., i.e., similar to the maximum altitude of forests in the Spanish Atlantic region (Díaz \& Fernández-Prieto 1987). At northern latitudes, the species shows a preference for temperate areas where extremely low winter temperatures are rarely occurring. However, it is also one of the few tree species that resists the most severe winter conditions in northern Spain. The distribution of $F$. sylvatica was also positively correlated with soil fertility, suggesting that the species prefers basic substrates. As F. sylvatica is known to grow in basic and acid soils in the study area, this distribution probably reflects the location of remnant beech forests in rich (calcareous) substrates.

Muñoz-Sobrino et al. (2008) identified an increase in the niche of $F$. sylvatica from the late Medium Holocene in the northwest of the Iberian Peninsula, which they attributed to the progressive warming in the area and the increased elevation of the tree line in the Cantabrian mountains. Our results are consistent with these previous findings, as $F$. sylvatica shows a clear preference for montane sites. Under such conditions (mountain climate at mid latitudes), F. sylvatica is highly competitive and is one of the main forest species in the Atlantic Region. The distribution of $Q$. petraea was established about 7000 years ago, as a result of the long-range recolonization after the last glaciation, according to fossil pollen data (Huntley \& Birks 1983). Similar to other deciduous oaks, during the Last Glacial Maximum this species was limited to small refugia in the Mediterranean region (Bennett et al. 1991), from where its spread northbound began. It is possible that similar shifts towards cool areas affected the distribution of this species in northern Spain, thus explaining its current distribution range at high elevations.

The geographic distribution of Quercus robur and Castanea sativa is mainly corre- lated with low-altitude areas and high minimum temperatures. Although $Q$. robur extends to high latitudes (up to $60^{\circ} \mathrm{N}$ - Repo et al. 2008), it is often limited by short vegetative periods and cold damage (Jensen 2000). Our findings are consistent with those of Attorre et al. (2012) who reported that the presence of $Q$. robur was correlated with the warm temperatures occurring in temperate areas of Italy, which suggests a preference of the species for relatively low altitudes. In our study, this results in a geographical disjunction between $Q$. petraea (restricted to cold sites) and $Q$. robur (dominating warm areas at low and medium altitude). Such disjunction is fairly uncommon in other European regions, where both species have similar distribution ranges, and their environmental niches are differentiated by soil moisture (EEA 2007). We also found that Q. robur was negatively correlated with fertility and positively correlated with the presence of acid soils.

Castanea sativa is less common in oceanic regions than $Q$. robur, mainly occurring in permanent forests of the Mediterranean region. The distribution of chestnut has been closely associated with human activity over the last 2000 years, as it has been intensively planted and harvested in the Iberian peninsula since Roman times, and its fruit was an important food in Medieval Ages as well (Conedera et al. 2004). Interestingly, the distribution of $C$. sativa has been related to low altitudes with annual rainfall between 700 and $1100 \mathrm{~mm}$ in both Mediterranean (Rubio et al. 2002) and Atlantic regions (Blanco et al. 2000). Our findings suggest that this species formed refugia in warm areas of temperate regions, which are probably more similar to the wettest areas of the Mediterranean regions. Indeed, the study area is considered a refuge for this species during several glacial events (Krebs et al. 2004) and pollen evidence demonstrates its presence prior to human impacts. In addition, we also detected spatial aggregation of such species, suggesting that its spread may have been locally favored to some extent by human intervention.

Although $B$. pubescens was positively correlated with the presence of acid soils, we did not find any clear geographical pattern in relation to the distribution of this species. These findings confirm the acidophilous nature of $B$. pubescens in the Atlantic region, unlike other biogeographical regions where birch can grow in different conditions along a soil mineralization gradient (EEA 2007). Betula species have been studied from different perspectives in botanical studies (Peinado \& Moreno 1989, Ceballos \& Ruíz de la Torre 2001), but no studies have focused on the ecological niche of these species in the Iberian peninsula. The relatively poor performance of the distribution models indicates that there are no clear climatic constraints to the local distribution of this species, which occurs on acid soils at any altitude in the study area. Betula pubescens is widely distributed in the Atlantic Region (Sykes et al. 1996), and its historical importance in northern Spain is often emphasized as it played a role as a colonizer after the Last Glacial Maximum (Muñoz Sobrino et al. 2006).

Finally, the model performed very poorly for $Q$. pyrenaica in the study area. In biogeographical terms, this species occupies intermediate zones between Atlantic forests of Q. robur and Mediterranean xerophytic forest dominated by Quercus ilex L. (CastañoSantamaria et al. 2013), and this species may not be sufficiently well represented in the study area for a good characterization of its niche. Such specific conditions - commonly referred as submediterranean climate - are not frequent in the study area, where $Q$. pyrenaica shows a scattered distribution on acid and dry soils in both mountain and coastal areas. This species also occupies a wide altitudinal range in Galicia (which is also part of the Spanish Atlantic region) in between 300 and $1300 \mathrm{~m}$ a.s.1., and in areas with low precipitation $\left(750 \mathrm{~mm}\right.$ year $^{-1}$. Diaz-Maroto et al. 2006, 2007). According to these authors, $Q$. pyrenaica requires lower summer precipitation (115 $\mathrm{mm}$ from June to August) than $Q$. robur $(165 \mathrm{~mm})$ and it is located in colder areas further from the sea. This is consistent with the location of the optimal area for this species in the Mediterranean region of the Iberian peninsula (Sánchez de Dios et al. 2009).

\section{Conclusions}

This study analyzed the strong altitudinal gradient of the Spanish Atlantic region and identified the minimum annual temperature as the main factor affecting the geographic distribution of tree species. Soil fertility was also an important predictor, as suggested by the good performance of distribution models for other forest species (Gaston et al. 2009).

Although landscapes in the Iberian peninsula have been greatly modified by human activities, the study area still comprises important portions of the remnant Atlantic deciduous forests (Garcia et al. 2005). Forest ecosystems are well represented, and the sampling carried out was larger enough to ensure the environmental niche assessed to be sufficiently representative of the species requirements. Nonetheless, we also recognize that in some cases historical reasons may underlie the current species distribution, especially at low altitudes (e.g., Quercus robur) and for those species most influenced by human activities (e.g., Castanea sativa), therefore puzzling the interpretation of the model outputs. In particular, the distribution of $C$. sativa appears to be spatially clustered, possibly due to the effect of past human influence (Conedera et al. 2004). On the other 
hand, we found meaningful explanations for the observed distributional patterns of the other species, in most cases fully consistent with their autoecological requirements. In addition, we also detected divergent niches for $Q$. petraea and $Q$. robur that have not previously been reported in Europe. Suitability of oceanic and humid-cool conditions was also confirmed for Betula pubescens and Fagus sylvatica, respectively. Overall, the information provided contributes to a better understanding of the distribution of deciduous forests in the European Atlantic biogeographical region.

\section{Acknowledgements}

JVRD is in receipt of a "Severo Ochoa" PhD Grant provided by FICYT-Government of Principado de Asturias (BP 12-093). BJA is grateful for financial support from the European Social Fund and the Government of the Czech Republic (Postdoc II, CZ.1.07/2. $3.00 / 30.0037)$. Funding of this work was provided by the project UNOV-13-EMERG13 (Universidad de Oviedo). We are grateful to an anonymous reviewer for her/his constructive comments on an earlier version of the manuscript.

\section{References}

Álvarez MA, Marquínez J (2007). Impacto de los incendios forestales en Asturias. Análisis de los últimos 30 años. Principado de Asturias [Impact of forest wildfires in Asturias: An analysis of last 30 years]. INDUROT, Universidad de Oviedo, KRK Ediciones, Oviedo, Spain, pp. 208. [in Spanish]

Ashcroft MB, French KO, Chisholm L (2011). An evaluation of environmental factors affecting species distributions. Ecological Modelling 222 (3): 524-531. - doi: 10.1016/j.ecolmodel.2010. 10.003

Attorre F, Francesconi F, Sanctis M, Alfò M, Martella F, Valenti R, Vitale M (2012). Classifying and mapping potential distribution of forest types using a finite mixture model. Folia Geobotanica 1-23. - doi: 10.1007/s12224-012-9139-8

Benito Garzón M, Sánchez de Dios R, Sainz Ollero H (2008). Effects of climate change on the distribution of Iberian tree species. Applied Vegetation Science 11 (2): 169-178. - doi: 10.31 70/2008-7-18348

Bennett KD, Tzedakis PC, Willis KJ (1991). Quaternary refugia of north European trees. Journal of Biogeography 18: 103-115. - doi: 10.2307/ 2845248

Blanco A, Rubio A, Sánchez O, Elena R, Gómez V, Graña D (2000). Autoecología de los castañares de Galicia (España) [Autoecology of sweet chestnuts trees in Galicia (Spain)]. Investigación Agraria Sistemas y Recursos Forrestales 9 (2): 337-361. [in Spanish]

Brus DJ, Hengeveld GM, Walvoort DJJ, Goedhart PW, Heidema aH, Nabuurs GJ, Gunia K (2011). Statistical mapping of tree species over Europe. European Journal of Forest Research 131 (1):
145-157. - doi: 10.1007/s10342-011-0513-5 Casalegno S, Amatulli G, Bastrup-Birk A, Houston Durrant T, Pekkarinen A (2011). Modelling and mapping the suitability of European forest formations at $1-\mathrm{km}$ resolution. European Journal of Forest Research 130: 971-981. - doi: 10.1007/ s10342-011-0480-x

Castaño-Santamaría J, Barrio-Anta M, ÁlvarezÁlvarez P (2013). Regional-scale stand density management diagrams for Pyrenean oak (Quercus pyrenaica Willd.) stands in north-west Spain. iForest 6 (1): 113-122. - doi: 10.3832/ ifor0880-006

Conedera M, Krebs P, Tinner W, Pradella M, Torriani D (2004). The cultivation of Castanea sativa (Mill.) in Europe: from its origin to its diffusion on a continental scale. Vegetation History and Archeobotany 13: 161-179. - doi: 10.1007/ s00334-004-0038-7

Ceballos L, Ruíz de la Torre J (2001). Arboles y arbustos de la España peninsular [Trees and shrubs of the Iberian Peninsula]. Fundación Conde del Valle de Salazar. Ediciones Mundi-Prensa, Madrid, Spain, pp. 512. [in Spanish]

Díaz TE, Fernández-Prieto JA (1987). Asturias y Cantabria [Asturias and Cantabria]. In: "La vegetación de España" (Peinado M, Rivas-Martínez S eds). Universidad de Alcalá de Henares, Madrid, Spain, pp. 77-116. [in Spanish]

Díaz TE, Fernández-Prieto JA (1994). La vegetación de Asturias [The vegetation of Asturias]. Itinera Geobotanica 8: 243-528. [in Spanish]

Diaz-Maroto I, Vila-Lameiro P, Guchu E, DiazMaroto M (2007). A comparison of the autecology of Quercus robur L. and Q. pyrenaica Wild.: present habitat in Galicia, NW Spain. Forestry 80 (3): 223-239. - doi: 10.1093/forestry/cpm019

Diaz-Maroto IJ, Vila-Lameiro P, Diaz-Maroto, MC (2006). Autecology of sessile oak (Quercus petraea) in the north-west Iberian Peninsula. Scandinavian Journal of Forest Research 21 (6): 458-469. - doi: 10.1080/02827580601066119

EEA (2007). European forest types. Categories and types for sustainable forest management reporting and policy ( $2^{\text {nd }}$ edn). EEA Technical Report no 9/2006, European Environment Agency, Copenhagen, Denmark, pp. 111.

EEA (2011). Biogeographical regions. European Environment Agency, Copenhagen, Denmark. [online] URL: http://www.eea.europa.eu/dataand-maps/data/biogeographical-regions-europe-1 Elith J, Leathwick JR (2009). Species distribution models: ecological explanation and prediction across space and time. Annual Review of Ecology Evolution and Systematics 40: 677-97. - doi: 10.1146/annurev.ecolsys.110308.120159

Fang J, Lechowicz J (2006). Climatic limits for the present distribution of beech (Fagus L.) species in the world. Journal of Biogeography 33: 1804-1819. - doi: 10.1111/j.1365-2699.2006.01 533.x

Fernández-Menéndez S (2002). Variables geomorfológicas y modelos predictivos de la distribución espacial de propiedades edáficas [Geomorphologic variables and predictive models of the spatial distribution of edaphic properties]. Me- moria de tesis doctoral, Universidad de Oviedo, Mieres, Spain, pp. 327. [in Spanish]

Fielding AH, Bell JF (1997). A review of methods for the assessment of prediction errors in conservation presence/absence models. Environmental Conservation 24 (1): 38-49. - doi: 10.1017/S037 6892997000088

Garcia D, Quevedo M, Obeso J, Abajo A (2005). Fragmentation patterns and protection of montane forest in the Cantabrian range (NW Spain). Forest Ecology and Management 208 (1-3): 2943. - doi: 10.1016/j.foreco.2004.10.071

Gaston A, Soriano C, Gómez-Miguel V (2009). Lithologic data improve plant species distribution models based on coarse-grained ocurrence data. Investigación Agraria Sistemas y Recursos Forestales 18 (1): 42-49.

Guisan A, Thuiller W (2005). Predicting species distribution: offering more than simple habitat models. Ecology Letters 8 (9): 993-1009. - doi: 10.1111/j.1461-0248.2005.00792.x

Harrison PA, Vandewalle M, Sykes MT, Berry PM, Bugter R, Bello F, Feld CK, Grandin U, Harrington R, Haslett JR, Jongman RH, Luck GW, Silva PM, Moora M, Settele J, Sousa JP, Zobel M (2010). Identifying and prioritising services in European terrestrial and freshwater ecosystems. Biodiversity and Conservation 19 (10): 2791-2821. - doi: 10.1007/s10531-010-978 9-x

Huntley B, Birks HJB (1983). An atlas of past and present pollen map for Europe: 0-13000 BP. Cambridge University Press, Cambridge, UK, pp. 302.

IGN (2013). MDT5. Web site, Instituto Geográfico Nacional, Spain. [online] URL: http://www. 01.ign.es/ign/main/index.do

Jensen J (2000). Provenance variation in phenotypic traits in Quercus robur and Quercus petraea in Danish provenance trials. Scandinavian Journal of Forest Research 15: 297-308. - doi: $10.1080 / 028275800447922$

European Commission (2012). Species distribution: tree species maps and species habitat suitability. European Forest Data Centre, Joint Research Centre, European Commission. [online] URL: http://forest.jrc.ec.europa.eu/efdac/applications/species-distribution/

Krebs P, Conedera M, Pradella M, Torriani D, Felber M, Tinner W (2004). Quaternary refugia of the sweet chestnut (Castanea sativa Mill.): an extended palynological approach. Vegetation History and Archeobotany 13: 145-160. - doi: 10.1007/s00334-004-0048-5

MA (2005). Ecosystems and human well-being: synthesis. Millenium Assessment, Island Press, Washington, DC, USA, pp. 137.

Meeus JHA (1995). Pan-European landscapes. Landscape and Urban Planning 31:57-79. - doi: 10.1016/0169-2046(94)01036-8

Metzger MJ, Bunce RGH, Jongman RHG, Mücher CA, Watkins JW (2005). A climatic stratification of the environments of Europe. Global Ecology and Biogeography 14: 549-563. - doi: 10.1111/j.1466-822X.2005.00190.x

MMA (2003). Tercer inventario forestal nacional: 
principado de Asturias [Third Spanish National Forest Inventory: Asturias]. Subdirección General de montes, Dirección General de Conservación de la Naturaleza, Secretaría General de Medio Ambiente, Ministerio de Medio Ambiente, Madrid, Spain, pp. 203. [in Spanish]

Muñoz-Sobrino CM, Ramil-Rego P, Gomez-Orellana L, Diaz-Varela RA (2005). Palynological data on major Holocene climatic events in NW Iberia. Boreas 343: 381-400. - doi: 10.1080/0300 9480510013006

Muñoz Sobrino C, Ramil-Rego P, Gómez-Orellana $L$ (2006). Late Würm and early Holocene in the mountains of northwest Iberia: biostratigraphy, chronology and tree colonization. Vegetation History and Archeobotany 16(4): 223-240. doi: 10.1007/s00334-006-0083-5

Muñoz-Sobrino C, Ramil-Rego P, Gómez-Orellana L, Ferreiro da Costa J, Díaz Varela RA (2008). Climatic and human effects on the postglacial dynamics of Fagus sylvatica L. in NW Iberia. Plant Ecology 203 (2): 317-340. - doi 10.1007/s11258-008-9552-5

Ninyerola M, Pons X, Roure JM (2005). Atlas climático de la península Ibérica. Metodología y aplicaciones en bioclimatología y geobotánica [Climatic Atlas of the Iberian Peninsula. Methodology and use for bioclimatology and geobotany]. Universidad Autónoma de Barcelona, Barcelona, Spain, pp. 44.

Ninyerola M, Serra-Díaz JM, Lloret F (2010). Topo-climatic suitability atlas of woody plants. Map server. Universidad Autónoma de Barcelona, Barcelona, Spain. [online] URL: http:// www.opengis.uab.es/wms/IdoneitatPI/index.htm Peinado M, Moreno G (1989). The genus Betula
(Betulaceae) in the Sistema Central (Spain). Willdenowia 18: 343-359. [online] URL: http:// www.jstor.org/stable/3996352

Repo T, Mononen K, Alvila L, Pakkanen TT, Hänninen H (2008). Cold acclimation of pedunculate oak (Quercus robur L.) at its northernmost distribution range. Environmental and Experimental Botany 63 (1-3): 59-70. - doi: 10.10 16/j.envexpbot.2007.10.023

Record S, Fitzpatrick MC, Finley AO, Veloz S, Ellison AM (2013). Should species distribution models account for spatial autocorrelation? A test of model projections across eight millennia of climate change. Global Ecology and Biogeography 22: 760-771. - doi: 10.1111/geb.12017

Rubio A, Sánchez-Palomares O, Gómez V, Graña D, Elena R, Blanco A (2002). Autoecología de los castañares de Castilla (España) [Autoecology of sweet chestnuts trees of Castilla (Spain)]. Investigación Agraria Sistemas y Recursos Forestales 11 (2): 373-393. [in Spanish]

Sánchez de Dios R, Benito-Garzón M, SainzOllero H (2009). Present and future extension of the Iberian submediterranean territories as determined from the distribution of marcescent oaks. Plant Ecology 204 (2): 189-205. - doi: 10.1007/ s11258-009-9584-5

Sánchez O, Rubio A, Blanco A, Gómez REV (2003). Autoecología paramétrica de los hayedos de Castilla y León [Parametric autoecology of Beech forest of Castilla y Leon]. Investigación Agraria Sistemas y Recursos Forestales 12: 87100. [in Spanish]

Schultz J (2005). The Ecozones of the world. The Ecological Divisions of the Geosphere ( $\left.2^{\text {nd }} \mathrm{edn}\right)$, Springer Verlag, New York, USA, pp. 252.
SPSS Inc. (2008). SPSS Statistics for Windows, Version 17.0. SPSS Inc., Chicago, IL, USA. Svenning JC, Skov F (2004). Limited filling of the potential range in European tree species. Ecology Letters 7: 565-573. - doi: 10.1111/j.1461-0248. 2004.00614.x

Svenning JC, Skov F (2007). Could the tree diversity pattern in Europe be generated by postglacial dispersal limitation? Ecology Letters 10: 453-460. - doi: 10.1111/j.1461-0248.2007.0103 $8 . \mathrm{x}$

Swets J (1988). Measuring the accuracy of diagnostic systems. Science 240: 1285-1293. - doi: 10.1126/science. 3287615

Sykes MT, Prentice IC, Cramer W (1996). A bioclimatic model for the potential distributions of north European tree species under present and future climates. Journal of Biogeography 23 (2): 203-233. [online] URL: http://www.jstor.org/stable/2845812

Thornthwaite CW (1948). An approach toward a rational classification of climate. Geographical Review 38: 55-94. - doi: 10.2307/210739

Tuhkanen S (1980). Climatic parameters and indices in plant geography. Acta Phytogeographica Suecica 67, Uppsala, Sweden, pp. 110.

Walter H (1979). Vegetation of the earth and ecological systems of the geo-biosphere $\left(2^{\text {nd }} e d n\right)$. Springer Verlag, New York, USA, pp. 276.

Willner W, Di Pietro R, Bergmeier E (2009). Phytogeographical evidence for post-glacial dispersal limitation of European beech forest species. Ecography 32 (6): 1011-1018. - doi: 10.1111/j. 1600-0587.2009.05957.x 